\title{
Strategic thinking and its related factors in a medical science university in Iran
}

\author{
Sedigheh Salavati ${ }^{1}$, Effat Jahanbani Veshareh ${ }^{2}$, Hossein Safari ${ }^{1}$, Amir Veysian ${ }^{3}$, Ghanbar Amirnezhad ${ }^{4}$
}

${ }^{1}$ Ph.D. Student of Health Policy, Department of Health Management and Economics, School of Public Health, Tehran University of Medical Science, Tehran, Iran

${ }^{2}$ Ph.D. of Health Services Management, Assistant Professor, Department of Health Services Management, School of Health, Ahvaz Jundishapour University of Medical Science, Ahvaz, Iran

${ }^{3}$ M.Sc. of Executive Management, Department of Management, Islamic Azad University, Ahvaz, Iran

${ }^{4}$ Ph.D. of Human Resource Management, Assistant Professor, Department of Management, Islamic Azad University, Ahvaz, Iran

\section{Type of article: Original}

\begin{abstract}
Background: Having strategic thinking is necessary in order to anticipate future changes and make strategic decisions. This study was carried out to assess the strategic thinking level in managers and personnel of Ahvaz Jundishapour University of Medical Science (AJUMS) - a public university in Iran.

Methods: It was a cross-sectional and analytical study and all managers (50) as well as a sample of personnel (200) from AJUMS participated in it. A researcher-made questionnaire was used in order to measure four dimensions of strategic thinking, including system thinking, futurism, conceptual thinking, and intelligent opportunism along with demographic and organizational characteristics of respondents. Statistical analysis was done by Freedman ranking test, one-way ANOVA, and Independent-samples t-test in SPSS software version 16.

Results: Strategic thinking in managers $(5.62 \pm 0.51)$ and personnel $(5.22 \pm 0.4)$, was evaluated at a somewhat high level. The maximum score among strategic thinking dimensions in managers (5.62 \pm 0.42$)$ and personnel $(5.52 \pm 0.43)$ was related to conceptual thinking that was in "good" level. A significant relationship was seen between intelligent opportunism dimension with job location in managers and education degree in personnel $(\mathrm{p} \leq 0.005)$. Also, there was a significant relationship between future dimension in managers and personnel with education degrees $(\mathrm{p} \leq 0.005)$. There was a significant difference between managers and employees in future dimension $(\mathrm{p}=0.018)$.

Conclusion: It seems that the participants have acceptable strategic thinking levels, although there is still room for improvement. Therefore, considering the factors such as educational development of managers and personnel can be very useful in this regard.

Keywords: Strategic thinking, System thinking, Conceptual thinking, Intelligence opportunism, Futurism, University
\end{abstract}

\section{Introduction}

Health care organizations face a fast changing and threatening environment (1). Such changes come from new policies and programs, national and international economic forces, demographic transition, lifestyle shifts, and technological advances. These new and continuing environmental forces require healthcare organizations to be increasingly careful in thinking about their strategies (2). Ability to develop effective strategies, which consider the above-mentioned changes, as well as the ability to manage the momentum of the organization, is collectively referred to as strategic management, and leads to better organizational performance and survival (3). Swayne et al. believe that strategic management has three elements - strategic thinking, strategic planning, and managing strategic momentum. Activities in all elements affect each other (4). Strategic planning and strategic thinking are interrelated and are equally important for effective strategic management. Moreover, creative and ground breaking strategies

\section{Corresponding author:}

Amir Veysian, Department of Management, Islamic Azad University, Ahvaz, Iran.

Tel: +98.6133738345, Email: veysian.a@gmail.com

Received: October 19, 2016, Accepted: January 22, 2017, Published: May 2017

iThenticate screening: January 25, 2017, English editing: March 02, 2017, Quality control: April 01, 2017

(C) 2017 The Authors. This is an open access article under the terms of the Creative Commons Attribution-NonCommercialNoDerivs License, which permits use and distribution in any medium, provided the original work is properly cited, the use is non-commercial and no modifications or adaptations are made. 
emerge from strategic thinking (5). Leaders who are able to think and act strategically will be able to create more supportive organizational environments and achieve more valuable organizational outcomes (6). According to Mintzberg, who is known as one of the foremost advocates of strategic thinking, strategic thinking is a particular way of thinking and a synthesizing process that uses creativity to produce "an integrated perspective of enterprise". He says that the planner should provide the formal analysis or hard data that strategic thinking requires, as long as they do it to expand the consideration of issues rather than discover the one right answer (7). Prahalad and Hamel refer to "strategic architecture" instead of strategic thinking and they emphasize on the elements of strategy-making including creativity, exploration, and understanding discontinuities (8). Hamel suggests five preconditions for the emergence of strategy: new voices, new conversations, new passions, new perspectives and new experiments (9). Raimond divides strategic thinking into two modes: "strategy as an intelligent machine" and "strategy as creative imagination". He introduced two foresights; predictive and creative approaches. The former is for recognizing the key forces which will shape the future and related outcomes. The latter involves key people in creating a vision of the future that, ideally, they will have, as well as the planning tools to make it happen (10). Strategic thinking includes both thinking and acting within a certain set of assumptions. Potential action alternatives as well as existing challenging assumptions and action alternatives will potentially lead to new and more appropriate ones (11). One model for strategic thinking was developed by Liedtka and is hypothesis-driven, intent-focused, intelligently opportunistic, and incorporates a systems perspective (12). Goldman believes that strategic thinking is (1) conceptual, in that the content is at an abstract level; (2) systems oriented, in that the thinking involves the whole organization and its rela $\neg$ tionship with the external environment; (3) directional, in that the concepts relate to an aimed-for future state; and (4) opportunistic, in that the environment and competitive characteristics provide a basis for the desired direction (13). Also, some researchers such as Bonn, Heracleous, Pisapia, Senge, and Scharmer, agree that three key components of strategic thinking are systems thinking, creativity and vision. Systematic thinking clarifies patterns and supports the effective changes, then it increases the creativity and, ultimately, the vision component provides a direction in decision making (14). In Iran, medical science universities have started to adapt strategic management and planning in recent years (15). Similar to other universities, Ahvaz Jundishapur University of Medical Sciences (AJUMS) has started to develop its strategic planning and related action plans for the next 5 years. Developing and implementing a successful strategic program in this university requires the personnel as well as the managers to be strategic thinkers. Moreover, strategic planning should occur after the strategic thinking and they are co-related processes that should support and complete each other $(7,16)$. Considering that AJUMS is almost at the initial steps of its strategic management, there is no published evidence regarding the different aspects of its strategic management. This study was prospected to determine the level of strategic thinking among the managers and personnel of AJUMS who were engaged in the strategic planning processes. In the present study, strategic thinking refers to four dimensions of systematic thinking, conceptual thinking, futurism, and intelligent opportunism. System thinking relates to an essential skill that leads to a deep understanding of dynamic relationship between components of problems (17). It contributes to goal-seeking and problem solving in organizational context (18). By determining the links and interrelationships of the whole system, patterns and themes will emerge which offer insights and new definition to the problems (19). Conceptual thinkers in organizations engage in creative discovery of hidden, but potentially viable, relations among concepts, thus, testing and extending such patterns of associations that otherwise may not be obvious or easily identified (20). Thinking about the future infers embracing change and being creative and flexible in decision making (21). Futurism includes understanding the future and being ready to make decisions for the future. It begins with identification of future options and identifies probability and utility of the options by evaluating them, and using available resources in the best way possible in line with the values (22). Furthermore, intelligent opportunism is related to the idea of openness to new experience that results in allowing people to take advantage of alternative strategies in order to respond to a rapidly changing business environment (11). The purpose of our study was to measure the strategic thinking in managers and personnel of AJUMS based on all 4 of these dimensions. Also, we determined the association between some demographic and organizational factors and strategic thinking dimensions.

\section{Material and Methods}

A cross sectional and analytical study was conducted in 2015 to determine the level of strategic thinking among personnel and managers in AJUMS as well as its related demographic and organizational factors. AJUMS, which is located in Khuzestan, a province in the southwest of Iran, is one of the 44 universities of medical sciences which are public and under the supervision of the Iranian Ministry of Health and Medical Education (MOHME). The university is responsible for provision of health care services and educating health and medical professionals at subnational level. The macro policies associated with recourse allocation, health services provision and professional education have been developed by MOHME, and the micro decision making has also been obligated to the 
universities. AJUMS educate students in health and medical fields, and at the same time, delivers health care services through its hospitals and health centers. It has a number of schools including health, nursing and midwifery, medicine, pharmacy, traditional medicine, dentistry, rehabilitation, and allied medical science, and students are graduated in bachelor, master and Ph.D. degrees from them. The AJUMS has a central headquarters which includes seven departments. These include treatment, drug and food, recourses development, education, research, health, culture and student departments. These departments are responsible for management and implementation of major policies which have been announced by MOHME and for developing the micro health policies at the provincial level. These departments were chosen as a research setting for the current study. Study population was all personnel and managers of AJUMS. We measured the strategic thinking of all the top, middle, and executive managers of AJUMS $(n=50)$. Also, study sample for determining the personnel strategic thinking was an estimated 200 based on Cochran formula $(\mathrm{N}=900, \mathrm{z}=1.96, \mathrm{p}=0.65, \mathrm{q}=0.35, \mathrm{~d}=0.05)$. Stratified random sampling was applied for choosing the participants; in a way that we assigned a code to each personnel and then they were randomly selected based on the numbers of personnel in each department. Some studies, models, and theories $(3,11-13,21)$ were used in order to develop a questionnaire for evaluating strategic thinking. The questionnaire includes five sections: 1) demographic and organizational characteristics of respondents, 2) twelve questions for system thinking evaluation, 3) sixteen questions to estimate conceptual thinking, 4) fifteen questions for futurism evaluation, and 5) sixteen questions to estimate the intelligent opportunism dimension. Figure 1 represents the dimensions of strategic thinking and some questions that were developed for measuring these dimensions. The questions were designed based on seven-option Likert scale. The measure to specify the strategic thinking level was defined based on the mean scores of questions for each dimension (1-1.87: very low strategic thinking level, 1.88-2.75: low level, 2.76-3.62: somewhat low level, 3.63-4.50: moderate level, 4.51-5.37: somewhat high level, 5.38-6.25: high level, 6.26-7: very high level). We assessed construct validity of questionnaire using a panel of experts. Also, Cronbach's alpha was measured $0.84,0.90,0.87$ and 0.80 for 12 system thinking, 16 conceptual thinking, 15 futurism evaluation, and 16 intelligent opportunism items, respectively. Data was analyzed by SPSS 16. Furthermore, $p<0.05$ was considered significant. Normality of data was determined using Kolmogorov Smirnov statistics. Friedman Test was also used for grading the four dimensions of strategic thinking. One-way ANOVA, Games Howell, and Tukey were applied to compare means of strategic thinking level based on demographic and organizational characteristics variables. Moreover, the statistical difference between managers and personnel in terms of their strategic thinking level was determined by independent $t$-test.

\section{Conceptual thinking}

- I am a risk taker even when there is a failure probability

- I am able to discover the relation between issues

- I can develop a framework for a problem or complicated situation for a better realization of the situation.

- I can apply the methods and concepts that I learn. - I can divide an issue into details.

- I can apply past trends for analyzing the current situations.

\section{System thinking}

- My performance affects the whole organization. - I realize the relation between organization and environment.

- I can find many ways for achieving a single goal.

- I like to be aware of results and impacts of organization performance.

- I know when and what I should do.

- I can direct my thought.

- I can imagine how different sectors of organizations perform with each other.

\begin{tabular}{|c|c|}
\hline Strate & nking \\
\hline $\begin{array}{l}\text { Futurism } \\
\text {-I can anticipate the repeatable trends and events. } \\
\text {-I have strong foresight and imagination } \\
\text { - I can describe the features of future activities. } \\
\text { - I know how our organizations can succeed in the } \\
\text { future. } \\
\text {-I can analyze the social, political, cultural, and economic } \\
\text { situations of communities regarding their current and } \\
\text { past condition. } \\
\text { - I believe that paying attention to future and planning } \\
\text { through foresight will result in time wasting for me and } \\
\text { my organization. (Negative question) }\end{array}$ & $\begin{array}{l}\text { Intelligent opportunism } \\
\text {-I can speak about events that will affect our work with } \\
\text { others. } \\
\text {-I listen to others actively. } \\
\text { - When I want to make decisions, I cannot trust others' } \\
\text { information and sights. (Negative question) } \\
\text { - It is important for me to use people's beliefs and ideas. } \\
\text { - I worry about putting aside the current routines and } \\
\text { replacing them with new ones. } \\
\text { - I believe that creativity should be a natural } \\
\text { phenomenon in the organization. } \\
\text {-It is important that our organization can compete with } \\
\text { others to achieve the competitive advantage. }\end{array}$ \\
\hline
\end{tabular}

Figure 1. Some questions of strategic thinking dimensions that were developed by researchers 


\section{Results}

Data were collected from 200 personnel and 50 managers in AJUMS. Demographic and organizational characteristics of respondents are presented in Table 1. Table 2 shows the level of strategic thinking dimensions for both managers and personnel. The strategic thinking level in managers (5.36 \pm 0.46$)$ and personnel $(5.22 \pm 0.40)$ were assessed in a somewhat high level.

Table 1. Demographic and organizational characteristics of respondents

\begin{tabular}{|c|c|c|c|}
\hline \multicolumn{2}{|l|}{ Variables } & Managers $(n=50)$ & Personnel $(\mathrm{n}=200)$ \\
\hline \multicolumn{2}{|l|}{ Age; mean (SD) } & $42.3(7.7)$ & $37.2(7.9)$ \\
\hline \multicolumn{2}{|l|}{ Sex (Male) } & $80.4 \%$ & $44.4 \%$ \\
\hline \multicolumn{2}{|l|}{ Marital (married) } & $87 \%$ & $71 \%$ \\
\hline \multirow[t]{5}{*}{ Education level } & High school & $2.2 \%$ & $8 \%$ \\
\hline & Post-secondary & $0 \%$ & $5.3 \%$ \\
\hline & Bachelor of science & $30.4 \%$ & $56.7 \%$ \\
\hline & Master of science & $21.7 \%$ & $20.3 \%$ \\
\hline & Ph.D. or physician & $43.5 \%$ & $8.6 \%$ \\
\hline \multirow{3}{*}{$\begin{array}{l}\text { Type of } \\
\text { employment }\end{array}$} & Tenure & $82.6 \%$ & $58.8 \%$ \\
\hline & Contractual & $13 \%$ & $33.7 \%$ \\
\hline & Corporation based & $0 \%$ & $6.4 \%$ \\
\hline \multicolumn{2}{|c|}{ Working experience years; mean (SD) } & $15.5(8.4)$ & $11.5(7.5)$ \\
\hline \multirow[t]{8}{*}{ Workplace } & Office of the head & $10.9 \%$ & $10.2 \%$ \\
\hline & Treatment department & $6.5 \%$ & $18.2 \%$ \\
\hline & Drug and food department & $6.5 \%$ & $13.9 \%$ \\
\hline & Recourses department & $10.9 \%$ & $11.8 \%$ \\
\hline & Education department & $21.7 \%$ & $14.4 \%$ \\
\hline & Research department & $17.4 \%$ & $4.8 \%$ \\
\hline & Health department & $8.7 \%$ & $17.6 \%$ \\
\hline & Culture and student department & $17.4 \%$ & $9.1 \%$ \\
\hline
\end{tabular}

Table 2. Mean and standard deviations of strategic thinking dimensions level

\begin{tabular}{|l|l|l|l|l|}
\hline \multirow{2}{*}{ Dimensions } & \multicolumn{2}{|l|}{ Managers } & \multicolumn{2}{l|}{ Personnel } \\
\cline { 2 - 5 } & Mean & SD & Mean & SD \\
\hline Conceptual & 5.62 & 0.51 & 5.52 & 0.43 \\
\hline Systematic & 5.29 & 0.46 & 5.24 & 0.52 \\
\hline Intelligent opportunism & 5.32 & 0.72 & 5.09 & 0.65 \\
\hline Futurism & 5.25 & 0.46 & 5.02 & 0.59 \\
\hline Strategic thinking & 5.36 & 0.46 & 5.22 & 0.40 \\
\hline
\end{tabular}

Results of the Friedman Test which was used for testing the differences between means of four strategic thinking dimensions are shown in Table 3. There is statistically a meaningful difference between scores of strategic thinking dimensions in managers $(\mathrm{p}<0.001)$. Therefore, conceptual thinking had the highest mean, and then the intelligent opportunism, futurism, and systematic thinking received the next highest mean, respectively. Also among personnel, there can be seen statistically, a meaningful difference between scores of strategic thinking dimensions $(p<0.001)$; conceptual thinking had the highest mean and then systematic thinking, intelligent opportunism, and futurism came after that, respectively (Table 2). Normality in data was consistent with Kolmogorov Smirnov statistics ( $\mathrm{p}=0.750$ ). Results of statistical hypothesis testing for determining mean of strategic thinking level based on demographic and organizational characteristics variables, showed managers who work at drug and food departments are higher in intelligent opportunism level ( $\mathrm{p}=0.04)$; In addition, the futurism level of managers was statistically different between educational levels $(\mathrm{p}=0.01)$; the higher the education level of managers, the higher their strategic thinking score (Table 4). There was not any statistically significant difference between managers' strategic thinking level based on their demographic characteristics. 
http://www.ephysician.ir

Table 3. Differences between means of strategic thinking dimensions based on Friedman Test

\begin{tabular}{|l|l|l|l|}
\hline Managers & Mean rank & \multicolumn{2}{|l|}{ Friedman Test } \\
\hline Conceptual & 3.30 & Numbers & 40 \\
\hline Systematic & 2.09 & Chi $^{2}$ & 21.88 \\
\hline Intelligent opportunism & 2.40 & $\mathrm{~F}$ & 3 \\
\hline Futurism & 2.21 & $p$-value & 0.000 \\
\hline Personnel & Mean rank & Friedman & Test \\
\hline Conceptual & 4.16 & Numbers & 166 \\
\hline Systematic & 2.99 & Chi $^{2}$ & 132.81 \\
\hline Intelligent opportunism & 2.69 & $\mathrm{~F}$ & 4 \\
\hline Futurism & 2.27 & $p$-value & 0.000 \\
\hline
\end{tabular}

Table 4. Strategic thinking dimensions score based on managers' organizational characteristic

\begin{tabular}{|c|c|c|c|c|c|}
\hline \multicolumn{2}{|l|}{ Variables } & $\begin{array}{l}\text { Conceptual } \\
\text { thinking; } \\
\text { mean (SD) }\end{array}$ & $\begin{array}{l}\text { System } \\
\text { thinking; } \\
\text { mean (SD) }\end{array}$ & $\begin{array}{l}\text { Opportunism } \\
\text {; mean (SD) }\end{array}$ & $\begin{array}{l}\text { Futurism; } \\
\text { mean }(\mathrm{SD})\end{array}$ \\
\hline \multirow[t]{6}{*}{ Education level } & High school & - & - & - & - \\
\hline & Post-secondary & - & - & - & - \\
\hline & Bachelor of science & $5.34(0.58)$ & $5.1(0.44)$ & $5.2(0.78)$ & $4.86(0.51)$ \\
\hline & Master of science & $5.77(0.41)$ & $5.52(0.48)$ & $5.36(0.69)$ & $5.54(0.51)$ \\
\hline & Ph.D. or physician & $5.71(0.49)$ & $5.32(0.46)$ & $5.38(0.75)$ & $5.35(0.52)$ \\
\hline & $p$-value & 0.17 & 0.17 & 0.91 & $0.01 *$ \\
\hline \multirow{4}{*}{$\begin{array}{l}\text { Type of } \\
\text { employment }\end{array}$} & Tenure & $5.59(0.54)$ & $5.28(0.48)$ & $5.32(0.76)$ & $5.2(0.6)$ \\
\hline & Contractual & $5.83(0.16)$ & $5.3(0.42)$ & $5.34(0.57)$ & $5.37(0.29)$ \\
\hline & Corporation based & - & - & - & - \\
\hline & $p$-value & 0.62 & 0.99 & 0.99 & 0.6 \\
\hline \multirow{7}{*}{$\begin{array}{l}\text { Working } \\
\text { experience (year) }\end{array}$} & $1-5$ & $5.83(0.28)$ & $5.32(0.4)$ & $5.5(0.82)$ & $5.48(0.59)$ \\
\hline & $6-10$ & $5.66(0.38)$ & $5.3(0.49)$ & $5.41(0.9)$ & $5.16(0.46)$ \\
\hline & $11-15$ & $5.76(0.66)$ & $5.5(0.56)$ & $5.24(0.63)$ & $5.48(0.6)$ \\
\hline & $16-20$ & $5.38(0.64)$ & $5.07(0.32)$ & $5.08(0.71)$ & $5.1(0.5)$ \\
\hline & $21-25$ & $5.67(0.32)$ & $5.5(0.64)$ & $5.46(0.62)$ & $5.16(0.59)$ \\
\hline & $>26$ & $5.39(0.71)$ & $4.96(0.48)$ & $5.23(0.93)$ & $4.94(0.67)$ \\
\hline & $p$-value & 0.49 & 0.18 & 0.88 & 0.38 \\
\hline \multirow[t]{9}{*}{ Workplace } & Office of the head & $5.61(0.57)$ & $5.31(0.63)$ & $5.36(0.74)$ & $5.14(0.56)$ \\
\hline & Treatment department & $6.06(0.53)$ & $5.5(0)$ & $5.25(0.65)$ & $5.02(0.3)$ \\
\hline & Health department & $5.1(0.59)$ & $5.19(0.45)$ & $4.56(0.86)$ & $5.08(0.56)$ \\
\hline & Drug and food department & $5.68(0.79)$ & $5.46(0.78)$ & $5.97(0.35)$ & $5.58(0.63)$ \\
\hline & Recourses department & $5.59(0.33)$ & $5.25(0.42)$ & $4.89(0.67)$ & $5.15(0.61)$ \\
\hline & Education department & $5.58(0.57)$ & $5.18(0.5)$ & $5.21(0.24)$ & $5.16(0.6)$ \\
\hline & Research department & $5.7(0.34)$ & $5.39(0.58)$ & $5.28(0.99)$ & $5.53(1.01)$ \\
\hline & Culture \& student department & $5.73(0.59)$ & $5.25(0.25)$ & $5.78(0.67)$ & $5.39(0.27)$ \\
\hline & $p$-value & 0.68 & 0.96 & $0.04 *$ & 0.7 \\
\hline
\end{tabular}

*Statistical difference in the mean of strategic thinking score based on organizational characteristic

Results of determining the strategic thinking level differences based on organizational characteristics are showed in Table 5. Results indicated that intelligent opportunism of personnel was statistically different based on their education level $(\mathrm{p}=0.001)$; personnel with higher education level were more intelligent opportunist. Futurism in personnel with a high school diploma was statistically lower than other personnel $(p=0.002)$. Strategic thinking level of personnel was not statistically different based on their work experience, workplace, or type of employment. Moreover, there was not statistically any difference between strategic thinking level with the age, sex, or marital status of personnel. Based on results of Independent-samples t-test which is presented in Table 6, there was a statistical difference between strategic thinking level of managers and personnel $(\mathrm{p}=0.05, \mathrm{df}=204, \mathrm{t}=-1.92)$. Furthermore, having the statistical difference between managers and personnel determined in each strategic thinking dimension, showed that there was not any statistical difference between managers and personnel in conceptual 
thinking, system thinking, or intelligent opportunism, with futurism dimension being the exception $(\mathrm{p}=0.018$, $\mathrm{df}=198, \mathrm{t}=-1.63)$.

Table 5. Strategic thinking dimensions score based on personnel's organizational characteristic

\begin{tabular}{|c|c|c|c|c|c|}
\hline \multicolumn{2}{|l|}{ Variables } & $\begin{array}{l}\text { Conceptual } \\
\text { thinking; } \\
\text { mean (SD) }\end{array}$ & $\begin{array}{l}\text { System } \\
\text { thinking; } \\
\text { mean (SD) }\end{array}$ & $\begin{array}{l}\text { Opportunism } \\
\text {; mean (SD) }\end{array}$ & $\begin{array}{l}\text { Futurism; } \\
\text { mean }(\mathrm{SD})\end{array}$ \\
\hline \multirow[t]{6}{*}{ Education level } & High school & $5.32(0.5)$ & $4.99(0.65)$ & $4.51(0.51)$ & $4.47(0.68)$ \\
\hline & Post-secondary & $5.54(0.3)$ & $5.16(0.57)$ & $4.71(0.89)$ & $5.37(0.56)$ \\
\hline & Bachelor of science & $5.52(0.43)$ & $5.25(0.5)$ & $5.2(0.62)$ & $5.03(0.6)$ \\
\hline & Master of science & $5.59(0.38)$ & $5.33(0.53)$ & $5(0.59)$ & $5.13(0.41)$ \\
\hline & Ph.D. or physician & $5.47(0.55)$ & $5.29(0.48)$ & $5.19(0.6)$ & $4.96(0.58)$ \\
\hline & $p$-value & 0.42 & 0.32 & $0.001 *$ & $0.002 *$ \\
\hline \multirow{4}{*}{$\begin{array}{l}\text { Type of } \\
\text { employment }\end{array}$} & Tenure & $5.56(0.41)$ & $5.25(0.49)$ & $5.1(0.64)$ & $5.04(0.58)$ \\
\hline & Contractual & $5.45(0.47)$ & $5.2(0.54)$ & $5.05(0.67)$ & $4.92(0.62)$ \\
\hline & Corporation based & $5.47(0.38)$ & $5.46(0.54)$ & $5.2(0.64)$ & $5.21(0.55)$ \\
\hline & $p$-value & 0.46 & 0.33 & 0.67 & 0.42 \\
\hline \multirow{7}{*}{$\begin{array}{l}\text { Working } \\
\text { experience years }\end{array}$} & $1-5$ & $5.43(0.44)$ & $5.2(0.5)$ & $5.1(0.65)$ & $5.02(0.48)$ \\
\hline & $6-10$ & $5.45(0.48)$ & $5.18(0.64)$ & $4.96(0.62)$ & $5.07(0.69)$ \\
\hline & $11-15$ & $5.72(0.3)$ & $5.42(0.42)$ & $5.18(0.59)$ & $5.06(0.7)$ \\
\hline & $16-20$ & $5.53(0.42)$ & $5.27(0.5)$ & $5.01(0.57)$ & $4.89(0.43)$ \\
\hline & $21-25$ & $5.52(0.36)$ & $5.15(0.51)$ & $5.2(0.86)$ & $5.04(0.75)$ \\
\hline & $>26$ & $5.83(0.93)$ & $5.1(0.48)$ & $5.39(0.84)$ & $5.13(0.76)$ \\
\hline & $p$-value & 0.06 & 0.39 & 0.55 & 0.83 \\
\hline \multirow[t]{9}{*}{ Workplace } & Head office & $5.48(0.45)$ & $5.31(0.41)$ & $5.27(0.7)$ & $5.16(0.41)$ \\
\hline & Treatment department & $5.57(0.42)$ & $5.34(0.53)$ & $5.12(0.67)$ & $5.02(0.65)$ \\
\hline & Health department & $5.57(0.46)$ & $5.19(0.61)$ & $4.99(0.61)$ & $4.84(0.6)$ \\
\hline & Drug and food department & $5.56(0.5)$ & $5.39(0.52)$ & $5.36(0.75)$ & $5.08(0.78)$ \\
\hline & Recourses department & $5.39(0.37)$ & $5.04(0.4)$ & $4.39(0.6)$ & $4.89(0.48)$ \\
\hline & Education department & $5.54(0.57)$ & $5.41(0.45)$ & $5.09(0.47)$ & $5.21(0.6)$ \\
\hline & Research department & $5.44(0.36)$ & $5.17(0.58)$ & $4.9(0.56)$ & $5.07(0.58)$ \\
\hline & Culture \& student department & $5.65(0.48)$ & $5.25(0.45)$ & $5.1(0.77)$ & $5.09(0.49)$ \\
\hline & $p$-value & 0.58 & 0.26 & 0.38 & 0.57 \\
\hline
\end{tabular}

*Statistical difference in the mean of strategic thinking score based on organizational characteristic

Table 6. Difference between strategic thinking level of managers and personnel based on independent-samples t-test

\begin{tabular}{|c|c|c|c|c|c|c|}
\hline \multirow{2}{*}{\multicolumn{2}{|c|}{ 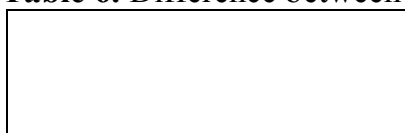 }} & \multicolumn{5}{|l|}{ Managers } \\
\hline & & $\begin{array}{l}\text { Strategic } \\
\text { thinking }\end{array}$ & $\begin{array}{l}\text { Conceptual } \\
\text { thinking }\end{array}$ & Futurism & Opportunism & $\begin{array}{l}\text { System } \\
\text { thinking }\end{array}$ \\
\hline \multirow[t]{5}{*}{ Personnel } & $\begin{array}{l}\text { Strategic } \\
\text { thinking }\end{array}$ & $\begin{array}{l}p=0.05 \\
\mathrm{df}=204, \mathrm{t}=-1.9\end{array}$ & - & - & - & - \\
\hline & $\begin{array}{l}\text { Conceptual } \\
\text { thinking }\end{array}$ & - & $\begin{array}{l}p=0.18 \\
\mathrm{df}=215, \mathrm{t}=-1.34\end{array}$ & - & - & - \\
\hline & Futurism & - & - & $\begin{array}{l}p=0.01, \\
\mathrm{df}=239, \mathrm{t}=2.19\end{array}$ & - & - \\
\hline & Opportunism & - & - & - & $\begin{array}{l}p=0.3, \mathrm{df}=218, \\
\mathrm{t}=-2.1\end{array}$ & - \\
\hline & $\begin{array}{l}\text { System } \\
\text { thinking }\end{array}$ & - & - & - & - & $\begin{array}{l}p=0.56 \\
\mathrm{df}=225, \mathrm{t}=- \\
0.58\end{array}$ \\
\hline
\end{tabular}

\section{Discussion}

This study was prospected to measure the strategic thinking level as well as its affecting factors in managers and personnel. The results demonstrated that strategic thinking is at a somewhat high level and there was a meaningful 
difference between managers and personnel in futurism dimension of strategic thinking. Both managers and personnel should have an acceptable level of strategic thinking and it is not only the senior managers' responsibility (23). Although, the AJUMS is in its initial experiences in developing strategic management and planning, it seems that the managers and personnel are really prepared to use the strategic thinking skills -futurism, system thinking, conceptual thinking, and intelligent opportunism- that were determined in our study. Having the previous studies done in Iran compared with our study's results, showed that the strategic thinking score in senior managers of a university in Tehran, the capital city of Iran, and some public organizations in another province, Kerman, was high $(24,25)$. Our study indicated that conceptual thinking in managers and personnel has the highest level in comparison with the other three dimensions of strategic thinking. Based on results of another study, strategic thinking includes system thinking, reflecting and reframing of accountants during adoption of the new Turkish commercial code. Results pointed out that system thinking and reflecting are the most frequently used skills (26). Results of another study that was conducted in an industrial company in Iran, the Zarsim Company, are also inconsistent with our results. According to that study, listening to new voices, welcoming new ideas, and creation of the enthusiasm in the organization were assessed at a good level and making the new intellectual frameworks was at an excellent level (27). Moreover, results of a study in the treatment department of Tehran University of Medical Science, another public university in Iran, were not similar to our results as they pointed out that new ideas, experiences, and conceptual thinking was at a low level (28). It appears that in our study the respondents had the ability to identify situations using patterns and integrating the issues and factors together in a conceptual framework, and benefit from the previous experiments. Also, based on the results, it seems that both personnel and managers welcome the new ideas and recognize their value in the problem solving. Creativity, applying regular and integrated ideas to reach goals, and challenging with current processes and instructions to improve them are the other aspects that respondents emphasized on. However, conceptual thinking is expandable and can be improved. Moreover, our findings revealed that after conceptual thinking, dimensions of the intelligent opportunism, futurism and system thinking were respectively assessed at a somewhat high level in the managers. However, in the case of personnel, dimensions of system thinking, intelligent opportunism, and futurism were respectively evaluated at a somewhat high level after the conceptual thinking. In previous research that was done at Tehran University of Medical Sciences, ranking the strategic thinking dimensions was not similar to our ranking scores and system thinking was at a good level, conceptual thinking and futurism were at a somewhat good level, and intelligent opportunism was at a medium level in that study. Additionally, managers at AJUMS were at a better level in terms of intelligent opportunism than Tehran University (24). Although, the level of systemic thinking, futurism, and intelligent opportunism is at a somewhat high level, the AJUMS needs to pay more attention to enhancing the strategic thinking level in order to be more successful against environmental changes, and to use its strengths and opportunities. We can try to develop system thinking skills using the experiences of other fields such as education system (29). Some system thinking skills include (30):

1) Shaping problems as patterns

2) Putting responsibility for a behavior on internal actors

3) Understanding the context of relationships

4) Emphasizing on causality and understanding how a behavior is created

5) Seeing causality as an ongoing process with the effect feeding back to influence the causes and the causes affecting each other.

The results suggest that there is no statistical difference between the managers' strategic thinking level and their age, sex, marriage status, job experience, and type of employment. As has been found in previous study, there was not any statistical relation between age and strategic thinking (24). In this study, managers with master degrees were significantly at higher level of futurism compared to the Ph.D. ones. Also, there is a significant relation between intelligent opportunism of managers with their workplace; managers who work in food and drug departments are at a higher level of intelligent opportunism. A statistical relation has been found between intelligent opportunism levels with education level of personnel; personnel with bachelor, master and Ph.D. degrees had higher intelligent opportunism. Kargin and Aktash did not report any significant relationship between the usage of strategic thinking skills with age, work experience, education level, and gender of accountants (26). It seems that the higher the education level of personnel, the more their ability in recognizing and using the external opportunities, predicting the outcomes of decisions, using others' thoughts and beliefs, and welcoming new processes. It is suggested that universities should try to promote the personnel's academic level through providing enough motivation and opportunity for them, and co-operating with those who want to get their higher academic degrees besides working in the organization. Our results revealed that there exists a significant relationship between academic education of personnel with higher futurism. These results can suggest that having academic education is related to other aspects, which describe futurism, such as explaining the most desirable future and convincing others to move towards that. In 
contrast with our results, another university-level study indicated no statistical relation between strategic thinking score with education level, but found a statistical relation between work experience with two dimensions of strategic thinking including system thinking and futurism, and managers with higher work experience had lower futurism and system thinking (26). One important limitation in this study is that we cannot generalize the results to managers and personnel of hospitals and health care centers which are managed by AJUMS because the nature of jobs and organization characteristics in staff and line departments are different.

\section{Conclusions}

This study was prospected to assess the strategic thinking level and its associated factors. It was found that conceptual thinking in managers and personnel was at a high level and the system thinking, intelligent opportunism, and futurism were at a somewhat high level. In addition to the work place, education levels of managers and personnel were also associated with strategic thinking levels. Our study provides research evidence for senior managers to identify the aspects of strategic thinking that require improvement and support decisions related to raising the strategic thinking level in personnel and managers. Investigating the solutions to enhance strategic thinking using qualitative studies as well as conducting the experimental studies to determine the effects of educational interventions aimed at enhancing strategic thinking are recommended for future studies.

\section{Acknowledgments:}

This article was extracted from a master's thesis in executive management. The authors would like to thank the entire personnel and managers who responded the questionnaire.

\section{Conflict of Interest:}

There is no conflict of interest to be declared.

\section{Authors' contributions:}

All authors contributed to this project and article equally. All authors read and approved the final manuscript.

\section{References:}

1) Williamson S. Fundamentals of strategic planning for healthcare organizations. London: Psychology Press; 1997.

2) Young DW, Ballarin E. Strategic decision - making in healthcare organizations: it is time to get serious. Int J Health Plann Manage. 2006; 21(3): 173-91. doi: 10.1002/hpm.844. PMID: 17044545.

3) Bonn I. Improving strategic thinking: a multilevel approach. LODJ. 2005; 26(5): 336-54. doi: 10.1108/01437730510607844.

4) Swayne LE, Duncan WJ, Ginter PM. Strategic management of health care organizations. England: John Wiley \& Sons; 2012.

5) Hernandez S, O'Connor S. Strategic Human Resources Management in Health Services, New York: Delmar Cengage Learning; 2011.

6) Uğurluoğlu Ö, Çelik Y, Pisapia J. Strategic Leader Actions Related to Effectiveness of Hospital Managers in Turkey. JBR. 2010; 3(1): 33-52.

7) Mintzberg H. The fall and rise of strategic planning. Harvard Bus Rev. 1994; 72(1): 107-14.

8) Prahalad CK, Hamel G. Strategy as a field of study: Why search for a new paradigm? SMJ. 1994; 15(S2): 5-16. doi: $10.1002 / \mathrm{smj} .4250151002$.

9) Hamel G. Strategy innovation and the quest for value. MIT SMR. 1998; 39(2): 7-14.

10) Raimond P. Two styles of foresight: are we predicting the future or inventing it? LRP. 1996; 29(2): 208-14. doi: 10.1016/0024-6301(96)00010-6.

11) Lawrence E. Strategic thinking. Discussion paper, Personnel Development and Resourcing Group, public service commission of Canada. Canada; 1999.

12) Liedtka JM. Strategic thinking: can it be taught? LRP. 1998; 31(1): 120-9. doi: 10.1016/S00246301(97)00098-8.

13) Casey AJ , Goldman EF. Enhancing the ability to think strategically: A learning model. Manage Learn. 2010; 41(2): 167-85. doi: 10.1177/1350507609355497.

14) Robinson DJ. A comparative, holistic, multiple-case study of the implementation of the strategic thinking protocol and traditional strategic planning processes at a southeastern university. Ph.D Thesis, Florida Atlantic University. ProQuest Dissertations Publishing; 2012. 
15) Ministry of health and medical education. The guideline for development and monitoring the operational programs at the universities of medical sciences. 2015. Available From: http://r3e.kums.ac.ir/kums_content/media/image/2016/06/83652_orig.pdf.

16) Thompson AA, Strickland AJ. Strategic management: Concepts and cases. McGraw-Hill/Irvin; 2001.

17) Jeong SH, Lee T, Kim IS, Lee MH, Kim MJ. The effect of nurses' use of the principles of learning organization on organizational effectiveness. J Adv Nurs. 2007; 58(1): 53-62. doi: 10.1111/j.13652648.2006.04206.x. PMID: 17394616.

18) Simon HA. The new science of management decision. USA: Prentice Hall PTR Upper Saddle River; 1977.

19) Arush B, Prabhakar K, Leena K. System Thinking, strategic planning. JIM. 2010; 7(4): 5-12.

20) Shafrir U, Kennet RS. Conceptual thinking and metrology concepts. Accred Qual Assur. 2010; 15(10): 585-90. doi: 10.1007/s00769-010-0669-6.

21) Van der Laan L. The imperative of strategic foresight to strategic thinking. JFS. 2008; 13(1): $21-42$.

22) Maroofi Y, Karami Z. Providence and futures study: A approach to curriculum development. IOJES. 2015; 7(3): 1-9. doi: 10.15345/iojes.2015.03.015.

23) Shaker Z, Nambisan S. Entrepreneurship and strategic thinking in business ecosystems. Bus Horis. 2012; 55(3): 219-29. doi: 10.1016/j.bushor.2011.12.004.

24) Moammai H, Amini M, Dargahi H, Mashayekh MR, Janbozorgi M. Strategic thinking measurement among staff managers of tehran university of medical science. JHA. 2013; 16(53): 73-84.

25) Saadati O, Sayadi S, Ahangari S. Study on relation between types of leadership styles with strategic thinking level in managers of public organizations in Kerman, Iran. J Prod Manag. 2013; 7(26): 69-91.

26) Karğın S, Aktaş R. Strategic Thinking Skills of Accountants During Adoption of IFRS and the New Turkish Commercial Code: A Survey from Turkey. Procedia Soc Behav Sci. 2012; 58: 128-37. doi: 10.1016/j.sbspro.2012.09.986.

27) Rezaee A. Assessment the strategic thinking based on Gary Hamel model in Zarsim Corporation. MSc Thesis, Payame Noor University, Iran. 2010.

28) Ahmadi S. Assessment the strategic thinking based on Gary Hamel model in treatment deputy of Tehran University of Medical Science. MSc Thesis, Payame Noor University, Iran. 2010.

29) Assaraf O, Orion N. Development of system thinking skills in the context of earth system education. J Res Sci Teach. 2005; 42(5): 518-60. doi: 10.1002/tea.20061.

30) De Savigny D, Adam T. Systems thinking for health systems strengthening. World Health Organization: geneva. 2009. 